\title{
Evaluation of the Injury Experiences of Healthcare Worker and the Measures taken, in a Training and Research Hospital
}

\author{
Ilknur Esen Yildiz \\ Recep Tayyip Erdogan University, Faculty of Medicine, \\ Department of Infectious Diseases, Rize, Turkey \\ E -mail: ilknuresen.yildiz@erdogan.edu.tr \\ Ilkay Bahceci (Corresponding author) \\ Recep Tayyip Erdogan University, Faculty of Medicine \\ Department of Medical Microbiology, Rize, Turkey \\ E-mail:bahceciie@ hotmail.com
}

\begin{abstract}
Aim:

Healthcare workers frequently carry out invasive procedures as part of their jobs. Regarding this situation, they are at risk for stab injuries and also for infectious diseases such as primarily hepatitis infections and Immune Deficiency Syndrome (HIV) depending on the contact of blood and body fluids to mucous membranes. Applying the infection control measures effectively is very important to reduce the risk of transmission. In this study, it was aimed to evaluate the occupational injuries in our hospital and to ensure the relevant measures by determining whether the necessary precautions were taken.
\end{abstract}

\section{Mehtod:}

Healthcare workers injuries which were occurred at Recep Tayyip Erdoğan University Education and Research Hospital between 2016 and 2018 were investigated retrospectively. After the records of the infection control committee were examined retrospectively in the first two years, the rate of injury was found to be high, once a month, by the Infectious Diseases Specialist, Medical Microbiology Specialist and Infection Control Committee. Face-to-face training seminars were given to reduce the changes in the data in the last three months of 2018 , when the training was given.

\section{Results:}

A total of 220 healthcare workers were included in our study in 3 years. The average age of the workers was $26.4 \pm 4.1$ years, and the female / male ratio was found as 143/77. In all three years, injuries were seen most commonly in nurses, second in intern students. After the trainings, the greatest reduction in the injury rates was observed in injectör needle sting injuries. Among the hospital staff, the greatest decrease in the injuries was observed in the cleaning staff

\section{Conclusion:}

Healthcare workers should be followed up that whether or not take protective measures such as primarly active and passive immune prophylaxis and carry out infection control measures correctly and effectively, against the occupationally transmitted diseases. Feedback should be received for this purpose and in case of deficiencies, it should be ensured to raise awareness by regular and continuous trainings.

Keywords: Education, awareness, healtcare injury

DOI: $10.7176 / \mathrm{JHMN} / 75-01$ 


\title{
Bir Eğitim ve Araştırma Hastanesindeki Sağlık Çalışanlarının Yaralanma Deneyimlerinin ve Alınan Önlemlerin Değerlendirilmesi
}

\begin{abstract}
Özet
Giriş-Amaç:

Sağlık çalışanları mesleklerinin bir parçası olarak sıklıkla invaziv girişimler uygularlar. Bu duruma bağ 1 olarak, delici kesici alet yaralanması ve ayrıca kan ve vücut sıvılarının mukoza zarlarına temasına bağlı öncelikle hepatit enfeksiyonları ve Bağışıklık Eksikliği Sendromu (HIV) gibi bulaşıcı hastalıklar için risk altındadırlar. Enfeksiyon kontrol önlemlerinin etkili bir şekilde uygulanması, bulaşma riskini azaltmak için çok önemlidir. Bu çalışmada hastanemizdeki mesleki yaralanmaların değerlendirilmesi ve gerekli tedbirlerin alınıp alınmadığını belirleyerek ilgili önlemlerin alınması amaçlanmıştır.
\end{abstract}

\section{Metod:}

Recep Tayyip Erdoğan Üniversitesi Eğitim Araştırma Hastanesinde 2016- 2018 yılları arasında meydana gelen hastane personel yaralanmaları retrospektif olarak incelenmiştir. Enfeksiyon kontrol komitesinin kayıtlarından ilk iki yıl içinde meydana gelen kesici delici alet yaralanmaları ve mukoza yaralanmaları geriye dönük olarak incelendikten sonra yaralanma oranının yüksek olduğu tespit edilmiştir.2018 yılının ilk üç ayında ayda bir olmak üzere Enfeksiyon Hastalıkları uzmanı, Tıbbi Mikrobiyoloji Uzmanı ve Enfeksiyon Kontrol Komitesi tarafindanyaralanmaları azaltmaya yönelik yüz yüze eğitim seminerleri verilmiştir Eğitimlerin verildiği 2018 yılının son üç ayında da verilerdeki değişiklikler değerlendirilmiştir.

\section{Bulgular:}

Çalışmaya 3 yıl içinde toplam 220 sağlık çalışanı dahil edilmiştir. Çalışanların yaş ortalaması 26,4 $\pm 4,1$ yıl olup, kadın /erkek oranı 143/77 olarak bulunmuştur. Her üç yılda da en fazla yaralanma hemşirelerde, ikinci sıklıkta ise stajyer öğrencilerde görülmüştür. Eğitimlerden sonra, yaralanma oranlarındaki en büyük düşüş enjektör iğnesi batması yaralanmalarında gözlenmiştir. Hastane personeli arasında, yaralanmalarda en büyük düşüş temizlik personelinde gözlenmiştir.

\section{Sonuç:}

Sağlık çalışanlarının mesleki olarak bulaşabilecek hastalıklara karşı, öncelikle aktif ve pasif immün proflaksi olmak üzere koruyucu tedbirleri alıp almadığı, enfeksiyon kontrol önlemlerini doğru ve etkin biçimde uygulayıp uygulamadığı takip edilmelidir. $\mathrm{Bu}$ amaçla geri bildirimler alınmalı, eksikliklerin olması durumunda düzenli ve sürekli olarak eğitimlerle farkındalığın artırılmaya çalışılması sağlanmalıdır.

Anahtar Kelimeler: Personel yaralanması, eğitim, farkındalık

\section{Giriş}

Sağlık çalışanları meslekleri gereği girişimsel işlemler esnasında kesici delici aletlere, kan ve vücut sıvılarına maruz kalmaları nedeniyle başta Hepatit B, Hepatit C ve HIV olmak üzere bulaşıcı enfeksiyonlara yakalanma açısından yüksek risk altında oldukları gibi kontamine aletlerle hastalığın bulaşması hem sağlık personeli hemde hasta için önemli bir risk faktörüdür [1-3].

Bulaş esas olarak perkutan ve mukozal yolla olmaktadır[2-4].Sağlık personeliyle yapılan çalışmalarda perkutan yaralanmaların mukozal yaralanmalara göre daha sıklıkta olduğu görülmüştür[5-7]. Yaralanmalar sıklıkla kesici delici aletlerle kan alma ya da damar yolu açılması gibi işlemler sırasında enjektör iğnesinin ucunun batması, enjektör kapağının kapatılması, ameliyatlarda kontamine sekresyonların göze sıçraması, cerrahi aletle yaralanma ya da çalışan biri ile çarpışma sonrasında görülmektedir. Bu temasların çoğu enfeksiyonla sonuçlanmamakla birlikte sağlık çalışanlarının sıklıkla karşılaştığ 1 bir durum olarak karşımıza çıkmaktadır.[3, 8].

Bulaşta enfeksiyon oluşumunda etkenin tipi, patojenitesi, bulaş tipi, viral yük, maruz kalınan kan miktarı önemlidir. Bulaş sonrası HBV enfeksiyon riski \%1-6, HCV enfeksiyon riski \%18, HIV enfeksiyon riski \%0,3 olarak bildirilmektedir. Özellikle temas öncesi aşı ile önlenebilen bulaşıcı hastalık olan HBV açısından tüm personelin bağışık olup olmadığı sorgulanmalı, bağışık olmayanların aşılı olup olmadıkları 
gözden geçirilmelidir. Temas sonrası etkene yönelik ilgili profilaksi en kısa sürede başlanmalıdır[3, 9, 10].

Bu çalışmada amacımız hastane personelimizin kesici delici alet yaralanma sıklığının, yaralanma şeklinin ve sonrasında Hepatit B, C ve HIV enfeksiyonu sıklığının tespit edilmesi, gerekli önlemlerin alınmasına yönelik eğitim düzenlemesinin yapılarak farkındalığın artırılması amaçlanmıştır.

\section{Yöntem}

2016-2018 tarihleri arasında Enfeksiyon Kontrol Komitesi (EKK) kayıtlarının retrospektif incelenmesine bağlı olarak kesici delici alet yaralanması ya da kan ve kontamine vücut sıvılarına maruz kalan sağlık çalışanları dahil edilmiştir. Dahil edilme kriterleri olarak; yaralanma sonrası enfeksiyon kontrol komitesine başvurulması ve sonrasında Personel Yaralanma Takip Formunun(PYTF) doldurulması belirlenmiş olup yaralanan personelin takipleri bu form ile gerçekleştirilmiştir. Yaralanma sonrası EKK başvurmayıp, yaralanma durumunu kayıt altına aldırmayan sağlık çalışanları çalışmaya dahil edilmemiştir. EKK'inin PYTF'daki yıllar içindeki değişimler retrospektif olarak incelenmiştir. Yaralanmaya maruz kalan personelin yaşı, cinsiyeti, meslek grupları (hemşire, doktor, temizlik personeli, paramedikal stajyer öğrenci, laboratuvar teknisyeni vb), yaralanma şekilleri (perkutan veya mukozal), yaralanma esnasında koruyucu ekipman kullanımı (tek eldiven,çift eldiven,gözlük, maske dahil tüm ekipmanın tam olması,ekipman kullanımının olmaması şeklinde), bulaş kaynağının kontaminasyon durumu (hepatit,B, C, HIV enfeksiyonlarının varlığı ya da yokluğu,enfeksiyon durumunun bilinmemesi), yaralanmaya maruz kalan sağlı personelinin bağışıklık durumu (hepatit B antikor varlığı, hepatit B bağışık değil, bağışıklık durumu bilinmiyor, ek aşı önerilmesi), yaralanmanın yeri, maruziyet sonrası enfeksiyon gelişip gelişmediği, yaralanmanın nasıl gerçekleştiği sorularının yer aldığı PYTF değerlendirilmiştir. İlk iki yıldaki yaralanmalarda hataların hangi faktörlere bağlı olduğu sorgulanmıştır. Yaralanmaların takipleri hastane kalite yönetimi ve enfeksiyon kontrol komitesi tarafindan geliştirilen PYTF ile yapılmıştır.

Yaralanmalara yönelik etkenler saptanmış ve bunların ortadan kaldırılmasına yönelik eğitim seminerleri verilmiştir. Bu seminerler Enfeksiyon Hastalıkları Uzmanı, Mikrobiyoloji Uzmanı ve Enfeksiyon Kontrol Komitesi hemşiresi tarafından her serviste lokal olmak üzere o servisin personeline 40-45 dakika sürede, interaktif olarak birer aylık aralıklarla gerçekleştirilmiştir. Bunun yanı sıra eğitim seminerleri konferans salonunda tüm personelin katılması sağlanarak üç aylık aralıklarla iki kez tekrarlanmıştır. Ayrıca hastanemizde her yeni başlayan personele oryantasyon eğitimi içinde Personel yaralanmalarına yönelik eğitimlerle birlikte kişisel koruyucu ekipman kullanımı ve temel mikrobiyoloji eğitimleri de yapılmaktadır. Eğitim sonrası 2018 yılı PYTF verileri incelenerek 2016-2017 yılları arasındaki iki yıllık döneme ait bir iyileşme olup olmadığı değerlendirilmiştir.

Veriler SPSS 21.0 programı ile analiz edilmiştir. Yıllar arasındaki yaralanma sayıları İki Eş Arasındaki Farkın Önemlilik Testi (PairedSamples t Test) ve Bağımlı İki Grup Arasındaki Farkın Önemlilik Testi (Wılcoxon Testi) kullanılarak karşılaştırılmıştır. Anlamlılık düzeyi olarak p $<0.05$ alınmıştır. Çalışmamız için Recep Tayyip Erdoğan Üniversitesi Girişimsel Olmayan Etik Kurul'undan izin alınmıştır (Onay no:2019/148)

\section{Bulgular}

2016-2018 Enfeksiyon Kontrol Komitesinin personel yaralanma kayıtları incelendiğinde yaralanan kişi sayısı yıllara göre sırasıyla 78,76 ve 66 kişi olarak bulunmuştur. Meslek dağılımları incelendiğinde en çok yaralanmanın tüm yıllarda (sırasıyla \%38.5, 38.2 ve 43.9) oranları ile hemşirelerde olduğu görülmüştür. Bu dağılımı sırasıyla paramedikal stajyer öğrenciler ve temizlik personelinin takip ettiğ tespit edilmiştir. Yaralanan personel ile alakalı bilgiler Tablo 1' de gösterilmiştir. Eğitim sonrasındaki yılda (2018) personel olarak laboratuvar teknisyenlerinde bir artış varken hemşirelerde de istatiksel olarak anlamlı bir düşüş saptanmamıştır. Temizlik personellerinde istatiksel olarak anlamlı olmasa da yaralanmalarda azalma ve stajyer öğrencilerde istatiksel olarak anlamlı bir azalma olduğu belirlenmiştir. Yaralanma öncesi ekipman kullanımının (eldiven, maske vb) en fazla 2018 yılında olduğu tespit edilmiştir (Y1llara göre \%69.7, 73.3 ve 77.3).

Yaralanmaların her üç yılda da en sık dahili servislerde olduğu saptanmıştır. Yaralanmanın gerçekleştiği birimler Tablo 2'de özetlenmiştir. Cerrahi branş servislerinde ve kan alma biriminde yaralanmalar azalmış olarak tespit edilsede istatiksel olarak anlamlı bulunamamıştır ( $p$ değerleri sırasıyla 0,04 ve 0,05). Yoğun Bakım Ünitelerinde önce bir azalma sonra bir artış gözlenmiş olup bu durum istatiksel olarak anlamlı bulunmuştur $(0,02)$.

Başlangıç döneminde yaralanmaların en sık enjektör kapağının kapatılması esnasında ve kan alma (damar yolu açma ve damar yolundan iğnenin çıkarılması) esnasında olduğu tespit edilmiştir (\%20,5 ve \%17,9). Yaralanma şekillerinin yıllara göre dağılımı Tablo 3' te sunulmuştur. Buna göre; intramuskuler

3 I P a g e www.iiste.org 
enjeksiyon esnasında ve insülin iğnesini çıkarma işlemi sırasında yaralanmalarda eğitim seminerlerine rağmen artış saptanmıştır (p değerleri sırasıyla 0,04 ve 0,03). Buna karşılık damar yolu açma- kan alma esnasında yaralanma oranının azaldığı ve bunun istatiksel olarak anlamlı olduğu belirlenmiştir $(0,04)$.

Yaralanmanın kaynaklandığı hastaların enfeksiyon durumları incelendiğinde; toplamda üç yılda 19 tane $\mathrm{HBV}, 17$ tane HCV, bir tanede HIV enfeksiyonu olan hastayla temas sonrası gelişen personel yaralanması görülmüştür. Sağlık çalışanları ve hastaların bağışıklık durumu Tablo 4'te özetlenmiştir. HIV enfeksiyon teması olan bir personele immunproflaksi başlanmıştır. HBV yaralanması olan personelin tamamı HBV'ne karşı bağışık olduğu için HBV immünproflaksisi yapılmamıştır. Tüm personelin HBV, HCV, HIV enfeksiyonun varlığı açısından dördüncü hafta, üçüncü ay ve altıncı ayda takipleri yapılmıştır. Sağlık çalışanlarının hiçbirinde enfeksiyon gelişmediği tespit edilmiştir. Sağlık çalışanlarının bağışıklık durumu incelendiğinde özellikle yeni başlayan stajyer öğrenciler ve temizlik personelinde aşılanma durumunun eksik olduğu bulunmuştur.

Tablo 1.Sağlık çalışanlarının yaralanmalarında mesleklere göre dağılım

\begin{tabular}{|c|c|c|c|c|c|c|c|}
\hline \multirow[t]{2}{*}{ Görev } & \multicolumn{2}{|c|}{2016} & \multicolumn{2}{|c|}{2017} & \multicolumn{2}{|c|}{2018} & $\mathbf{p}$ \\
\hline & $\mathbf{n}$ & $\%$ & $\mathbf{n}$ & $\%$ & $\mathbf{n}$ & $\%$ & \\
\hline Doktor & 7 & 9,0 & 8 & 10,5 & 7 & 10,6 & 0,8 \\
\hline Hemşire & 30 & 38,5 & 29 & 38,2 & 29 & 43,9 & 0,79 \\
\hline Laboratuvar Teknisyeni & 1 & 1,3 & 0 & 0,0 & 2 & 3,0 & $\mathbf{0 , 0 3}$ \\
\hline Stajyer Öğrenci & 29 & 37,2 & 20 & 26,3 & 19 & 28,8 & 0,04 \\
\hline Temizlik Personeli & 9 & 11,5 & 19 & 25,0 & 8 & 12,1 & 0,09 \\
\hline Diğer & 2 & 2,6 & 0 & 0,0 & 1 & 1,5 & 0,03 \\
\hline Toplam & 78 & 100 & 76 & 100 & 66 & 100 & \\
\hline
\end{tabular}

Tablo 2.Yaralanmanın gerçekleştiği hastane birimleri

\begin{tabular}{lcccccccc} 
Birim & \multicolumn{2}{c}{$\mathbf{2 0 1 6}$} & \multicolumn{2}{c}{$\mathbf{2 0 1 7}$} & \multicolumn{2}{c}{$\mathbf{2 0 1 8}$} & $\mathbf{p}$ \\
\hline Dahili Branş Servisleri & $\mathbf{n}$ & $\mathbf{\%}$ & $\mathbf{n}$ & $\mathbf{\%}$ & $\mathbf{n}$ & $\mathbf{\%}$ & \\
Cerrahi Branş Servisleri & 37 & 47,4 & 36 & 47,4 & 35 & 53,0 & 0,2 \\
Ameliyathane & 10 & 12,8 & 10 & 13,2 & 7 & 10,6 & 0,4 \\
Kan alma & 5 & 6,4 & 8 & 10,5 & 7 & 10,6 & 0,8 \\
Acil Servis & 12 & 15,4 & 9 & 11,8 & 5 & 7,6 & 0,05 \\
Yoğun Bakım Üniteleri & 7 & 9,0 & 11 & 14,5 & 7 & 10,6 & 0,09 \\
Diğer (Atık deposu -çamaşırhane) & 1 & 1,3 & 2 & 2,6 & 1 & 1,5 & 0,7 \\
Toplam & 78 & & 76 & & 66 & &
\end{tabular}


Tablo 3. Personel yaralanmalarının gerçekleştiği durumlar

\begin{tabular}{|lcccccccc}
\hline & \multicolumn{2}{c}{$\mathbf{2 0 1 6}$} & \multicolumn{2}{c}{$\mathbf{2 0 1 7}$} & \multicolumn{2}{c}{$\mathbf{2 0 1 8}$} & $\mathbf{P}$ \\
\hline Bulaş Yolu & $\mathbf{n}$ & $\mathbf{\%}$ & $\mathbf{n}$ & $\mathbf{\%}$ & $\mathbf{n}$ & $\mathbf{\%}$ \\
\hline Çöp toplarken & 10 & 12,8 & 14 & 18,4 & 9 & 13,6 & 0,09 \\
\hline Herhangi bir şekilde iğne batması & 9 & 11,5 & 9 & 11,8 & 11 & 16,7 & 0,72 \\
\hline Insülin enjektörü batması & 5 & 6,4 & 7 & 9,2 & 14 & 21,2 & $\mathbf{0 , 0 3}$ \\
\hline $\begin{array}{l}\text { Cerrahi alet temizlerken veya } \\
\text { bistüriile travma }\end{array}$ & 5 & 6,4 & 7 & 9,2 & 6 & 9,1 & 0,09 \\
\hline $\begin{array}{l}\text { Intramuskülerenjeksiyon } \\
\text { esnasında iğne batması }\end{array}$ & 2 & 2,6 & 6 & 7,9 & 3 & 4,5 & $\mathbf{0 , 0 4}$ \\
\hline $\begin{array}{l}\text { Tıbbi atıkları tıbbi kutusuna } \\
\text { atarken yaralanma }\end{array}$ & 12 & 15,4 & 10 & 13,2 & 7 & 10,6 & 0,08 \\
\hline $\begin{array}{l}\text { Damar yolu açma- kan alma } \\
\text { esnasında yaralanama }\end{array}$ & 14 & 17,9 & 11 & 14,5 & 6 & 9,1 & $\mathbf{0 , 0 1}$ \\
\hline Enjektör kapağını kapatırken & 16 & 20,5 & 9 & 11,8 & 5 & 7,6 & $\mathbf{0 , 0 2}$ \\
\hline Pansuman yaparken & 2 & 2,6 & 2 & 2,6 & 0 & 0,0 & 0,62 \\
\hline Göze kan sıçraması & 3 & 3,8 & 1 & 1,3 & 5 & 7,6 & 0,05 \\
\hline Toplam & 78 & 100 & 76 & 100 & 66 & 100 &
\end{tabular}

Tablo 4.Sağlık çalışanları ve hastaların bağışıklık durumu

\begin{tabular}{|c|c|c|c|c|c|c|}
\hline \multicolumn{7}{|c|}{ Hastaların Bağışıklık Durumu } \\
\hline & \multicolumn{2}{|c|}{2016} & \multicolumn{2}{|c|}{2017} & \multicolumn{2}{|c|}{2018} \\
\hline & $\mathbf{n}$ & $\%$ & $\mathbf{n}$ & $\%$ & $\mathbf{n}$ & $\%$ \\
\hline HCV varlığı & 2 & 2,6 & 8 & 10,5 & 7 & 10,6 \\
\hline HIV varlığı & 0 & 0,0 & 0 & 0,0 & 1 & 1,5 \\
\hline HBV varlığı & 6 & 7,7 & 4 & 5,3 & 9 & 13,6 \\
\hline Bağışıklık durumu bilinmiyor & 39 & 50,0 & 31 & 40,8 & 27 & 40,9 \\
\hline Hepatit B ve C yok & 27 & 34,6 & 25 & 32,9 & 11 & 16,7 \\
\hline Hepatit B Bağışık & 4 & 5,1 & 8 & 10,5 & 11 & 16,7 \\
\hline Toplam & 78 & & 76 & & 66 & \\
\hline \multicolumn{7}{|c|}{ Sağlık Personelinin Bağışıklık Durumu } \\
\hline HBV bağışık & 45 & 57,7 & 46 & 60,5 & 39 & 59,1 \\
\hline HBV bağışık olmayıp aşı önerilen & 5 & 6,4 & 16 & 21,1 & 10 & 15,2 \\
\hline Bağışıklık durumu bilinmeyen & 16 & 20,5 & 3 & 3,9 & 12 & 18,2 \\
\hline Ek doz önerilen & 10 & 12,8 & 11 & 14,5 & 5 & 7,6 \\
\hline Hepatit enfeksiyonu varlığı & 2 & 2,6 & 0 & 0,0 & 0 & 0,0 \\
\hline Toplam & 78 & & 76 & & 66 & \\
\hline
\end{tabular}




\section{Tartışma}

Dünya Sağlık Örgütü verilerine göre her yıl sağlık çalışanlarında 385000 injektör yaralanması ve günde ortalama 1000 kesici alet yaralanması gerçekleşmektedir. Ayrıca Exposure Prevention Information Network (EPINet®) sisteminden elde edilen verilere göre ise yıllık ortalama, 100 yatak başına yaklaşık 30 iğne yaralanması gerçekleşmektedir ([10]. Bu durum Türkiye'de sağlık çalışanları açısından ciddi bir problem olmasına rağmen sistematik kayıt programındaki eksiklikler düşünülmekte ve yaralanma sıklı̆̆ına ilişkin ulusal verilerin yeterli olmadığı bildirilmektedir[11].

Sağlık çalışanları meslekleri gereği hem kesici-delici aletlerle yaralanmaya bağlı hem de kan ve vücut sıvılarının mukozaya temasına bağlı olarak yirmiden fazla mikroorganizmayla enfekte olma riski taşımaktadırlar. Fakat bu durum genellikle enfeksiyon kontrol önlemlerinin doğru ve etkin bir şekilde uygulanması ile engellenebilir [4, 12, 13].

Temas sonrası HBV kaynaktan bulaş durumunda kişide bağışıklık mevcut değilse HBV aşısı ile birlikte HBIg serumu uygulanmalıdır[3]. Çalışmamızın genelinde HBV enfeksiyonu teması olan personelin tamamının bağışık olduğu bulunmuştur. Bununla birlikte HBV hasta teması olmayan ya da temas durumu bilinmeyen sağlık çalışanları arasında, bağışık olmadığ saptanmıştır. Tüm personelin immün bağışık olmaması, özellikle stajyer öğrencilerin ve temizlik personelinin aşılarının yeterli olmayışı düzeltilmesi gereken önemli bir durum olarak görülmüş ve bu personeller aşılama programına alınmıştır.

Araştırmaların çoğunda kontamine kan ve vücut sekresyonlarına bağlı yaralanmalara maruz kalan personelin sıklıkla hemşireler olduğu saptanmıştır[7, 11, 14]. Bizim çalışmamızda da benzer şekilde personel yaralanmasının her üç yıldada en sıklıkla hemşirelerde olduğu bulunmuştur (üç yıl ortalaması \%40). Yaralanma oranının en yüksek oranda hemşirelerde görülmesinin nedeni invazif işlem sıklı̆̆ının en fazla bu grupta görülmesiyle açıklanabilir. Ayrıca bu durumun, hastanemizde çalışan hemşire sayısının yetersiz olmasına ve sık sık hemşire değişikliğinin olmasına bağlı olarak genç ve tecrübesiz personelin çalışmasından kaynaklandığı düşünülebilir. İkinci en sık yaralanan personelin ise stajyer öğrencilerde görülmüş olması (üç yıl ortalaması \%30,9) henüz mesleklerinin başında olan bu gruba eğitimlerin yapılıp farkındalığın artırılması gerekliliği sonucuna ulaştırmıştır. Ancak bazı çalışmalarda farklı meslek gruplarında farklı yaralanma oranları bildirilmiştir. Literatürde Merih ve arkadaşlarının çalışmasında \% 72 oranıyla en sık temizlik personelinde, Gücük ve arkadaşlarının çalışmasında ise en sık doktor grubunda bulunmuştur[15, 16]. Bu durum çalışmaya dahil edilen grupların farklı dağılımından, personelin farkındalığının aynı olmamasından, hastane şartlarının değişken olması gibi pek çok faktörden kaynaklanıyor olabilir.

Yaralanmaların olduğu birimler; hastanenin sınıfına, çalışma şartlarına, personel sayısının yeterli olup olmaması, personelin eğitimli ve tecrübeli olması gibi birçok duruma göre değişebilmektedir. Bozkurt ve arkadaşlarının, Azap ve arkadaşlarının çalışmalarında yaralanma en sık cerrahi servislerde görülürken; Aydın ve arkadaşlarının çalışmasında bizim çalışmamıza benzer şekilde yaralanmanın en sık dahili servislerde olduğu, Dizilli ve arkadaşlarının yaptığı çalışmada yine \% 47,6 ile yaralanmanın servislerde olduğu bu sırasıyla acil servis ve kan alma biriminin takip ettiği bildirilmiştir [11,17,18,19].Bu durum dahili birimlerde hematolojik problem, kronik enfeksiyon gibi tedavisi uzun süren hasta yatışları, özellikle kan alıp verme, tıbbi ilaç tedavisi gibi invaziv işlemlerin sık olmasıyla açıklanabilir. Bununla birlikte hastanemizdeki bu birimlerde sağlık çalışanlarının özellikle de hemşirelerin sürekli olarak değişmesi, yeni ve tecrübesiz personelin eğitim sürecinde olmalarının da katkısı olabilir. Bir diğer sorun ise özellikle cerrahi branşlarda ki hekimler olmak üzere bu bölümde çalışanların yaralanma durumlarını Enfeksiyon Kontrol Komitesine bildirmemelerinden kaynaklanabiliyor olmasıdır. İş kazaları birimlerinin sağlık çalışanları yaralanmalarını titizlikle takip edip kayıt altına almalarının personel yaralanma oranlarının daha gerçekçi olmasına katkı sağlayabilir.

Yaralanmaların gerçekleştiği olaylar; sıklıkla kan alma, enjektör kapağının kapatılması, tıbbi atık kutuna iğne ucu atma, çöp toplarken yaralanma şeklinde olmak üzere pek çok farklı şekilde bildirilmiştir[7, 14, 18].Kaya ve arkadaşları, Azap ve arkadaşlarının çalışmalarında en sık yaralanma sebebinin enjektör kapağının kapatılması sırasında ve ikinci sıklıkta ise damar yolu açılırken olduğu tespit edilmiştir[11, 20]. Bizim çalışmamızın ilk iki yılında en sık neden kan alma (damar yolu açma veya damar yolundan iğnenin çıkarılması) olarak bulunmuştur. Nedeni araştırıldığında; hasta başına tıbbi müdahale öncesi tıbbi malzeme tepsileriyle gidilmesi gerekirken özellikle yeni başlayan hemşirelerin bu duruma dikkat etmedikleri tespit etmişlerdir. Ayrıca iğneyi takma ya da çıkarma esnasında manüplasyona bağlı kendi ya da arkadaşlarının ellerine iğneyi batırmaları şeklindeki kazaların ağırlıklı olduğu saptanmıştır. Bu konuda farkındalığın artırılması için hizmet içi eğitimler tekrarlanmıştır. Ancak hastanemizin Eğitim Araştırma Hastanesi olması, sürekli şekilde hemşire değişikliğinin olması, genç ve tecrübesiz personelle çalışılıyor olması eğitim sonrası istenilen şekilde başarılı olamamamızın nedenleri olarak düşünülebilir. 
Yapılan gözlemlerde bir diğer önemli hata olarak; tıbbi atık çöp torbalarının doğru ve uygun endikasyonlarda kullanılmadığı, evsel atık çöp kutularının tıbbi atık çöp kutusu gibi kullanıldığı tespit edilmiştir. Buna bağlı olarak evsel atıkların toplanması esnasında iğne ucu, bistüri, cam kırığı gibi atıklara bağlı temizlik personelinin yaralandığı saptanmıştır. Yaralanmaların üçüncü sıklığında tıbbi atık kutularının aşırı dolu olmasına bağlı özellikle iğne ucu yaralanması şeklinde olduğu saptanmıştır. Bu durum bize konu ile farkındalığın yeterli olmadığını, denetimlerin daha sık yapılıp gerekirse yaptırımlar yapılması gerekliliği sonucuna ulaştırmıştır.

Eğitimler özellikle stajyer öğrenci, yeni başlayan hemşire ve temizlik görevlileri başta olmak üzere tüm sağlık çalışanlarına tekrarlanarak geri bildirim yapılmıştır. Eğitim sonrası yıl sonunda ki personel yaralanmaları değerlendirildiğinde eğitim öncesi iki yıla göre oransal olarak yaralanmalarda azalma gözlenmesine rağmen bu oran istenen düzeyde olmamıştır.

Kesici ve delici aletlerle çalışırken standart koruyucu önlemlerin uygulanması; el yıkama başta olmak üzere, koruyucu ekipmanların, tıbbi atık kutularının ve çöp kovalarının doğru ve uygun şekilde kullanılması personel yaralanmalarının azalmasını sağlayan etkili yöntemlerdir. $\mathrm{Bu}$ bağlamda bilgilendirmelerin yapılıp uygulamaların değerlendirilerek geri bildirimlerin alınması oldukça önemlidir. Çalışmamızda yaralanmaya maruz kalıp EKK'ne başvurarak PYTF'u dolduran bireyler alınmıştır. Eğitimlerin sonunda yaralanmaya maruz kalıp bu durumunu kayıt altına aldırmayan personellerin olduğu öğrenilmiştir. Bu durumun nedeni sorgulandığında yeni başlayan stajyer öğrencilerin bu konuda daha öncesinde eğitim almamış oldukları, farkındalık durumlarının iyi olmadıkları saptanmıştır. Bu nedenle yaralanan tüm personele ulaşılamamış olması ve onların maruziyet durumlarının irdelenememiş olması çalışmamızın kısıtlılıklarındandır. Ancak çalışmamızla birlikte geri bildirimlerin alınması, eğitimlerin sürekli yapılması takip eden yıllarda sağlık çalışanlarının yaralanma oranlarını azaltacaktır.

Sonuç: Hastanelerin kendi sağlık çalışanlarının bağışıklık durumlarını, yaralanmalarının sıklığını ve nedenlerini belirleyerek ilgili önlemlerin alınması, eğitimlerle farkındalığın artırılmaya çalışılması personel yaralanmalarındaki oranların iyileşmesine katkı sağlayacaktır. Hastaneye başlayan her personele oryantasyon eğitimi verilmesine karşın eğitim sadece bununla sınırlı kalmadan ideal aralıklarla ilgili birim personellerine bizzat kendi birimlerinde interaktif ve uygulamalı olarak verilmelidir. Devamında da geri dönüşler alınmalıdır.

Yazarlar arasında çıkar çatışması yoktur

\section{Kaynaklar:}

1. European Centre for Disease Prevention and Control. Hepatitis B and C in the EU neighbourhood: prevalence, burden of disease and screening policies [İnternet]. Stockholm: ECDC [erişim 30 Mayıs 2019]. https://www.ecdc. europa. eu/en /pub licationsdata/hepatitis-b-and-c-eu-neighbourhood-prevalence-burdendisease-andscreening. [CrossRef]

2. N, Y., Să̆lık personelinin hastane infeksiyonları açısından izlemi. . İnfeksiyon Dergisi 2000. 14: p. 357-366.

3. Tabak F, T.S., Viral Hepatit. İstanbul Tıp Kitabevi, 2013.

4. Trim JC, A.D., Elliott PT, Healthcare workers' knowledge of inoculation injuries and glove use. . British Journal of Nursing, 2003. 12(4): p. 215-221.

5. Ayranci U, K.N., Needlestick and sharps injuries among nurses in the healthcare sector in a city of western Turkey. Journal of Hospital Infection. , 2004. 58(3): p. 216- 223.

6. Kuruüzüm Z, E.Z., Günay S, Gündüz Ş, Yapan Z, Sağlık çalışanlarında kan ve beden sıvılarıyla oluşan mesleksel yaralanmalar: bir anket çalışması. Mikrobiyoloji Bülteni 2008. 42(1): p. 61-69.

7. Altıok M, K.F., Karaçorlu S, Ersöz G, Erdoğan S, Sağlık çalışanlarının delici kesici aletlerle yaralanma deneyimleri ve yaralanmaya yönelik alınan önlemler. Maltepe Üniversitesi Hemşirelik Bilim ve Sanatı Dergisi 2009. 2(3): p. 70-79. 
8. Cesur S, A.N., Toros GY, Tekin A, Altuntop A, Şencan İ. Etlik Ihtisas Eğitim ve Araştırma Hastanesi Sağlık Çalışanlarında Kesici- Delici Alet Yaralanmalarının Değgerlendirilmesi. Ortadoğu Medical Journal 2014. 6(4): p. 161 - 169.

9. Khurram M, I.K., Bushra HT, Khan NY, Bushra H, Hussain W, Needlestick injuries: a survey of doctors working at Tertiary Care Hospitals of Rawalpindi. J Pak Med Assoc, 2011. 61(1): p. 63-65.

10.National Institute for Occupational Safety and Health (NIOSH). Alert: Preventing Needlestick Injuries in Health Care Settings [İnternet]. Cincinnati, OH: NIOSHPublications Dissemination [erişim 30 Mayis 2019]. https://www. cdc. gov/ niosh /docs /2000-108/ pdfs/2000-108.pdf.

11.Azap A, E.Ö., Memikoğlu K, Yeşilkaya A, Altunsoy A, Y1lmaz BY, Tekeli E Occupational exposure to blood and body fluids among health care workers in Ankara, Turkey. American Journal of Hospital Pharmacy, 2005. 33(1): p. 1-66.

12.Wagner D, d.W.K., Huzly D, Hufert F, Weidmann M, Breisinger S, et al. , Nosocomial acquisition of dengue. Emerging infectious diseases, 2004. 10(10): p. 1872-1879.

13.Beltrami EM, M.M., McGeer A, Armstrong-Evans M, Lyons D, Chamberland ME, et al. , The nature and frequency of blood contacts among home healthcare workers. Infection Control \& Hospital Epidemiology, 2000. 21(12): p. 765-770.

14.Kesmez FC, S.S., kinci Basamak Bir Hastanede Sağlık Çalışanlarında Kesici-Delici Alet Yaralanmalarının Değerlendirilmesi J Contemp Med, 2017. 7(4): p. 373-377.

15.Gücük M, K.S., Yolsay N, Özden YI. , Istanbul Tıp Fakültesi Genel Cerrahi Kliniği Çalışanlarında Kesici-Delici Alet Yaralanmaları. Hastane İnfeksiyonları Dergisi, 2002. 6: p. 72-81.

16.Merih YD, K.M., Çırpı F, Bolca Z, Celayir AR, Bir devlet Hastanesinde 3 Yıl İçerisinde Görülen Kesici-Delici Alet Yaralanmalarının Epidemiyolojisi ve Korunmaya Yönelik Önlemler. Zeynep Kamil Tıp Bülteni, 2009. 49(1): p. 11-15.

17.Aydın NN, A.F., Yılmaz G, Köksal İ An Assesment Of Sharp Injuries In Health Care Workers. Viral Hepatitis Journal, 2018. 24(3): p. 75-78.

18.Bozkurt S, K.Ö.F., Yanıt F ve ark. , Să̆lık Çalışanlarında İğne Batması Ve Cerrahi Aletlerle Olan Yaralanmalar. Dicle T1p Dergisi, 2013. 40(3): p. 449-452.

19.Dizili-Yelgin C, Çıkman A, Karakeçili F, Gülhan B, Aydın M. Bir eğitim ve araştırma hastanesinde kesici ve delici alet yaralanmalarının değerlendirilmesi. Klimik Derg. 2018; 31(3): 200-4. [CrossRef]

20.Kaya Ş, B.B., Eşkazan AE, Çolak H, Diyarbakır Eğitim Araştırma Hastanesi Să̆lık Çalışanlarında Kesici Delici Alet Yaralanmalarının Değerlendirilmesi. Viral Hepatit Dergisi, 2012. 18(3): p. 107-110 